Article

\title{
Transformation of Propane over ZnSnPt Modified Defective HZSM-5 Zeolites: The Crucial Role of Hydroxyl Nests Concentration
}

\author{
Wei Zhou, Jiaxu Liu *, Jilei Wang, Long Lin, Ning He, Xiaotong Zhang and Hongchen Guo \\ State Key Laboratory of Fine Chemicals \& School of Chemical Engineering, Dalian University of Technology, \\ Dalian 116012, China \\ * Correspondence: liujiaxu@dlut.edu.cn; Tel./Fax: +86-411-8498-6162
}

Received: 11 May 2019; Accepted: 27 June 2019; Published: 28 June 2019

\begin{abstract}
A series of $\mathrm{ZnSnPt}$ supported defective MFI zeolites with different $\mathrm{SiO}_{2} / \mathrm{Al}_{2} \mathrm{O}_{3}$ ratios $(30,110$, 700 , and $\infty$ ) and hydroxyl nests concentration were prepared and characterized by multiple techniques including scanning electron microscopy (SEM), nitrogen physisorption, $\mathrm{NH}_{3}-\mathrm{TPD}$, transmission electron microscopy (TEM), hydrogen temperature programmed reduction $\left(\mathrm{H}_{2}-\mathrm{TPR}\right)$, and Fourier transform infrared spectrometer (FT-IR). It was found that Brønsted acid sites $(\mathrm{Si}(\mathrm{OH}) \mathrm{Al}$ ) with strong acid strength and the hydroxyl nests with weak acid strength coexisted over the defective ZSM-5 zeolites and $\mathrm{ZnSnPt}$ Lewis acid sites preferentially located on the hydroxyl nests. The increase in the concentration of hydroxyl nests and $\mathrm{SiO}_{2} / \mathrm{Al}_{2} \mathrm{O}_{3}$ ratios apparently improved the distribution of $\mathrm{ZnSnPt}$ Lewis acid sites. The hydroxyl nest incorporated $\mathrm{ZnSnPt}$ Lewis acid sites showed extraordinary dehydrogenation ability. Specially, operando dual beam Fourier transform infrared spectrometer (DB-FTIR) was applied to characterize the propane transformation under reaction conditions. At low $\mathrm{SiO}_{2} / \mathrm{Al}_{2} \mathrm{O}_{3}$ ratios, the propane efficiently transforms into propene and aromatics (total selectivity of $93.37 \%$ ) by the cooperation of Brønsted acid sites and $\mathrm{ZnSnPt}$ Lewis acid sites. While at high $\mathrm{SiO}_{2} / \mathrm{Al}_{2} \mathrm{O}_{3}$ ratios, the propane mainly transforms into propene (selectivity of above 95\%) and hydrogen. This study provides guidance for the preparation of highly efficient propane dehydrogenative transformation catalyst.
\end{abstract}

Keywords: defective MFI; hydroxyl nests; $\mathrm{ZnSnPt}$ Lewis acid sites; $\mathrm{Si}(\mathrm{OH}) \mathrm{Al}$; operando dual beam FT-IR spectroscopy

\section{Introduction}

Environmentally friendly and non-corrosive, solid acid catalysts (zeolites and zeolite-based catalysts) have been widely applied in numerous petrochemical processes [1]. A "hydroxyl-nest defect" over the silica-alumina zeolites was first produced by progressively removing the aluminum from the frameworks and substituting with nests of four hydroxyls [2]. Although the hydroxyl nests possess mild acidic properties [3-5], the catalytic function of the hydroxyl nests are seldom reported and merely testified to be effective in the Beckmann rearrangement [6-8]. The HZSM-5 zeolite with MFI topology has been widely employed in applications such as cracking, dehydrogenation, oligomerization, and aromatization due to their large surface area, excellent reactivity and stability, unique pore structure, and shape selectivity $[9,10]$. Usually, the upgrading of its catalytic performance depends on the posttreatments to adjust the acidic properties [11-14]. On account of the weak acidity of the hydroxyl nests, it provides another way for the designing of novel catalysts in heterogeneous reactions by regulating the ratio of hydroxyl nests to $\mathrm{Si}(\mathrm{OH}) \mathrm{Al}$ groups. 
High-efficiency transformation of light alkanes is one of the greatest challenges of the present catalysis research. The introduction of $\mathrm{Zn}, \mathrm{Ga}$, and $\mathrm{Pt}$ species into HZSM-5 improved the dehydrogenative aromatization performance and inhibited the cracking of side-reactions [13,15-18]. The Cyclar process was jointly developed by BP and UOP using Ga-Pt modified ZSM- 5 zeolite as the catalyst [19]. When propane was used as a feedstock, the aromatics yield announced was $63.1 \mathrm{wt} \%$ and the dry gas yield was $31 \mathrm{wt} \%$. Nevertheless, the extremely high selectivity of the by-products and high cost of Ga-Pt modification catalysts hampered its further development. According to literature and our previous work, Zn modified HZSM- 5 zeolites are effective catalysts for the dehydrogenative aromatization of light alkanes and exhibit comparable catalytic performance to Ga-Pt loaded ZSM-5 zeolite [20-31]. However, the generation of substantial amounts of dry gas (methane and ethane) by-products has inhibited the large-scale application of the light alkanes dehydrogenative aromatization over the Zn supported HZSM-5 zeolite [32-35]. According to our previous study [36], the addition of $\mathrm{SnPt}$ into $\mathrm{Zn} / \mathrm{HZSM}-5$ apparently improved the propane dehydrogenative aromatization performance. However, due to the low $\mathrm{SiO}_{2} / \mathrm{Al}_{2} \mathrm{O}_{3}$ ratio of HZSM-5, the Brønsted acidity and metal dispersion were not at the optimal status. Moreover, we found that $\mathrm{Zn}$ modified defective HZSM- 5 catalysts obtained better performance than regular HZSM- 5 catalysts in hexane aromatization, and the hydroxyl group stabilized Zn species exhibited better dehydrogenative performance [37].

Therefore, in this study, a series of ZnSnPt modified defective MFI zeolites (ZSM-5 and silicalite-1) with different $\mathrm{SiO}_{2} / \mathrm{Al}_{2} \mathrm{O}_{3}$ ratios $(30,110,700$ and $\infty)$ and hydroxyl nests concentration are systematically studied. It is found that $\mathrm{ZnSnPt}$ Lewis acid sites are preferentially located on the hydroxyl nests with weak acidity rather than on the $\mathrm{Si}(\mathrm{OH}) \mathrm{Al}$ groups with strong acidity, and the size of metal particles is smaller and much more uniform at higher concentration of the hydroxyl nests. These $\mathrm{ZnSnPt}$ Lewis acid sites located on the hydroxyl-nest defects show superior propane dehydrogenation performance. For the $\mathrm{ZnSnPt}$ modified HZSM-5 zeolite with low $\mathrm{SiO}_{2} / \mathrm{Al}_{2} \mathrm{O}_{3}$ ratio of 30, the selectivity of propylene and BTX (benzene, toluene, xylene) is $52.92 \%$ and $40.45 \%$, respectively, while the selectivity of $C_{1}-C_{2}$ alkanes is only $6.63 \%$. For the $\mathrm{ZnSnPt}$ modified HZSM-5 zeolite with high $\mathrm{SiO}_{2} / \mathrm{Al}_{2} \mathrm{O}_{3}$ ratio of $\infty$, propane mainly transforms into propene (above $95 \%$ selectivity) and hydrogen. Operando dual beam Fourier transform infrared spectrometer (FTIR) study unravels that the acidity of neighboring active sites over $\mathrm{ZnSnPt}$ Lewis acid sites located hydroxyl nests determines the transformation paths.

\section{Results and Discussion}

\subsection{Defective MFI Zeolites Supported by $\mathrm{Zn}-\mathrm{Sn}$-Pt with Different $\mathrm{SiO}_{2} / \mathrm{Al}_{2} \mathrm{O}_{3}$ Ratios}

As shown in the scanning electron microscopy (SEM) images in Figure 1, the introduction of Zn, Sn, Pt into HZSM- 5 zeolites with different $\mathrm{SiO}_{2} / \mathrm{Al}_{2} \mathrm{O}_{3}$ ratios by impregnation has little influence on the crystal size and morphology (Figure 1). According to the XRD (X-ray diffraction) patterns shown in Figure S1, five characteristic diffraction peaks of the MFI structure are preserved [5] and no diffraction signals for metal species are observed, indicating that the metal species are highly dispersed. 


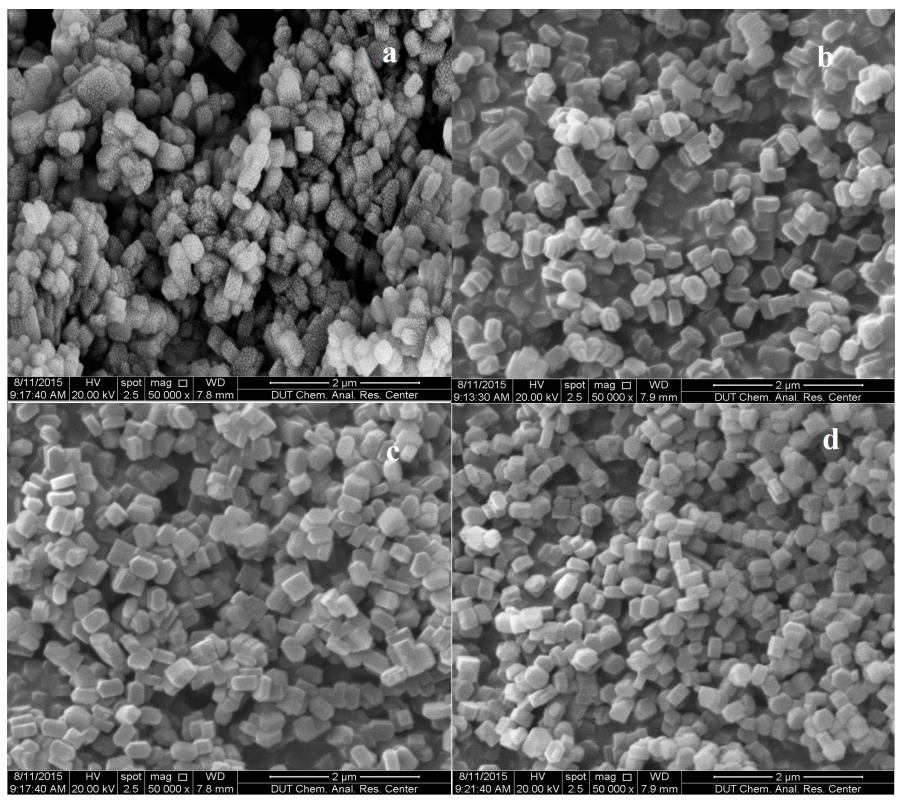

Figure 1. Scanning electron microscopy (SEM) images of defective MFI zeolites with different $\mathrm{SiO}_{2} / \mathrm{Al}_{2} \mathrm{O}_{3}$ ratios. (a) HZ30, (b) $\mathrm{HZ110}$, (c) HZ700, (d) S-1.

According to the nitrogen physisorption results (Table 1), some important specifics related to the locations of $\mathrm{Zn}, \mathrm{Sn}$, and $\mathrm{Pt}$ on the $\mathrm{ZnSnPt} / \mathrm{MFI}$ catalysts are found. The external surface area and the mesoporosity of $\mathrm{ZnSnPt}$ modified defective MFI catalysts obviously decreased compared with that of the parent zeolites. The external surface of the parent nano-MFI crystals in the aggregates formed the inter-crystal mesopores as revealed by the pore size distribution (Figure 2). After the modification with $\mathrm{Zn}, \mathrm{Sn}$ and Pt species, the inter-crystal mesopores apparently decreased. Based on the abovementioned results, it is assumed that parts of the metals are located on the external surface of the catalysts. Moreover, it can be seen that the specific surface area and pore capacity of micropores also decrease after loading $\mathrm{ZnSnPt}$. It is reasonable to deduce that some of the $\mathrm{ZnSnPt}$ metal particles are located inside the zeolite channels.

Table 1. Textural properties of the parent and $\mathrm{Zn}-\mathrm{Sn}-\mathrm{Pt}$ modified defective MFI zeolites with different $\mathrm{SiO}_{2} / \mathrm{Al}_{2} \mathrm{O}_{3}$ ratios.

\begin{tabular}{ccccccccc}
\hline Sample & \multicolumn{3}{c}{ HZSM-5 } & \multicolumn{4}{c}{ ZnSnPt/HZSM-5 } \\
\hline $\mathbf{S i O}_{\mathbf{2}} / \mathbf{A l}_{\mathbf{2}} \mathbf{O}_{\mathbf{3}}$ & $\mathbf{3 0}$ & $\mathbf{1 1 0}$ & $\mathbf{7 0 0}$ & $\boldsymbol{\infty}$ & $\mathbf{3 0}$ & $\mathbf{1 1 0}$ & $\mathbf{7 0 0}$ & $\boldsymbol{\infty}$ \\
\hline $\mathrm{S}_{\mathrm{BET}}{ }^{\mathrm{a}}$ & 425 & 342 & 380 & 443 & 364 & 291 & 293 & 354 \\
$\mathrm{~S}_{\text {micro }}{ }^{\mathrm{b}}$ & 334 & 232 & 232 & 364 & 310 & 212 & 196 & 324 \\
$\mathrm{~S}_{\text {extern }}{ }^{\mathrm{b}}$ & 91 & 110 & 148 & 79 & 54 & 79 & 97 & 30 \\
$\mathrm{~V}_{\text {pores }}{ }^{\mathrm{b}}$ & 0.35 & 0.27 & 0.28 & 0.30 & 0.24 & 0.23 & 0.21 & 0.22 \\
$\mathrm{~V}_{\text {micro }}{ }^{\mathrm{b}}$ & 0.23 & 0.14 & 0.14 & 0.16 & 0.18 & 0.13 & 0.13 & 0.12 \\
$\mathrm{~V}_{\text {meso }}{ }^{\mathrm{c}}$ & 0.12 & 0.13 & 0.14 & 0.14 & 0.06 & 0.10 & 0.08 & 0.10
\end{tabular}

a BET method applied to the $\mathrm{N}_{2}$ isotherm. ${ }^{\mathrm{b}} t$-Plot method applied to the $\mathrm{N}_{2}$ isotherm. ${ }^{\mathrm{c}} V_{\text {meso }}=V_{\text {pore }}-V_{\text {micro }}$. $V_{\text {pore }}$ was determined from the amount of $\mathrm{N}_{2}$ adsorbed at $p / p^{0}=0.99$. 

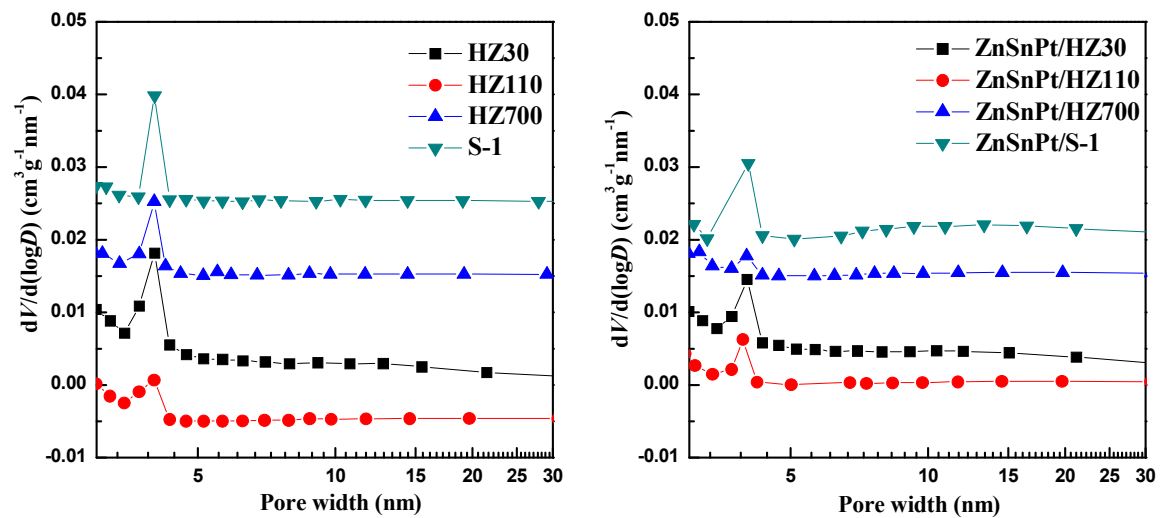

Figure 2. Pore size distribution of defective MFI zeolites (a) and Zn-Sn-Pt modified defective MFI zeolites (b) with different $\mathrm{SiO}_{2} / \mathrm{Al}_{2} \mathrm{O}_{3}$ ratios.

\subsection{Metallicity of $\mathrm{ZnSnPt}$ Lewis Acid Sites over Defective MFI Zeolites with Different $\mathrm{SiO}_{2} / \mathrm{Al}_{2} \mathrm{O}_{3}$ Ratios}

TEM was carried out to obtain the direct information about metal dispersion on $\mathrm{ZnSnPt} / \mathrm{MFI}$ catalysts. As shown in Figure 3, the average size of metal particles is larger than $4 \mathrm{~nm}$ over the $\mathrm{ZnSnPt} / \mathrm{HZ} 30$ catalyst. Moreover, it was found that the metal dispersion further enhanced with increase in the $\mathrm{SiO}_{2} / \mathrm{Al}_{2} \mathrm{O}_{3}$ ratios. Over $\mathrm{ZnSnPt} / \mathrm{S}-1$, the metal particles decreased to 0-3 nm centering at less than $2 \mathrm{~nm}$. These results suggest that small-sized metal particles are obtained at a high concentration of hydroxyl nests, as seen in Figure $3 \mathrm{~d} . \mathrm{H}_{2}$-TPR is performed to illustrate the interaction between the metals. In Figure S2, SnPt/HZ30 catalyst has only one hydrogen consumption peak at $645 \mathrm{~K}$ that is between $\mathrm{Pt} / \mathrm{HZ} 30$ and $\mathrm{Sn} / \mathrm{HZ} 30$ catalysts. This phenomenon suggests the formation of $\mathrm{SnPt}$ alloy particles on the $\mathrm{SnPt} / \mathrm{HZ} 30$ catalyst. Based on our previous work [38], there is no hydrogen consumption peak on the $\mathrm{Zn} / \mathrm{HZ} 30$ catalyst, and a hydrogen consumption peak at a high temperature attributed to strong interaction between the zinc and platinum species of $\mathrm{Zn}_{1.0} \mathrm{Pt}_{0.1} / \mathrm{HZ} 30$ catalyst. As shown in Figure 4, there are two hydrogen consumption peaks over the $\mathrm{ZnSnPt}$ modified defective MFI zeolites: One at around $633 \mathrm{~K}$, which is associated with the formation of SnPt alloys; and the other at a high temperature, which shows strong interaction between zinc and platinum species. Thus, the $\mathrm{H}_{2}$-TPR characterization provided more convincing evidences for the formation of SnPt alloys and the interaction between platinum and small $\mathrm{ZnO}$ cluster. 


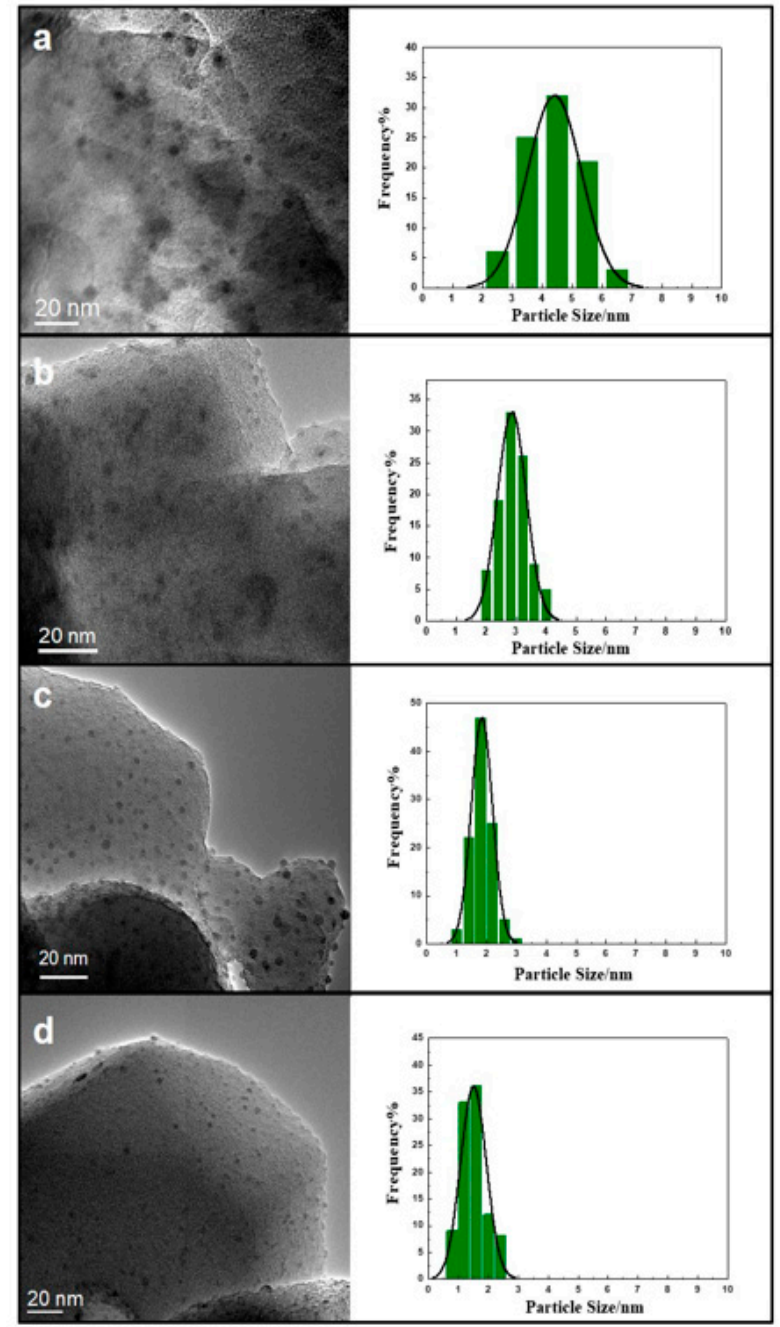

Figure 3. TEM images and particles size distribution of $\mathrm{Zn}-\mathrm{Sn}-\mathrm{Pt}$ modified defective MFI zeolites with different $\mathrm{SiO}_{2} / \mathrm{Al}_{2} \mathrm{O}_{3}$ ratios. (a) $\mathrm{ZnSnPt} / \mathrm{HZ30}$, (b) $\mathrm{ZnSnPt} / \mathrm{HZ110}$, (c) $\mathrm{ZnSnPt} / \mathrm{HZ700,} \mathrm{(d)} \mathrm{ZnSnPt} / \mathrm{S}-1$ catalysts.

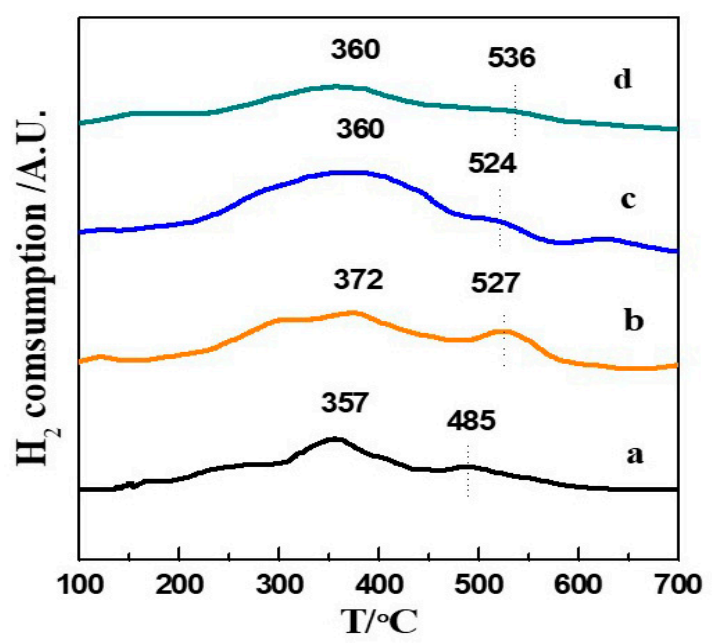

Figure 4. $\mathrm{H}_{2}-\mathrm{TPR}$ profiles of $\mathrm{ZnSnPt}$ modified defective MFI zeolites. (b) ZnSnPt/HZ110; (c) ZnSnPt/HZ700; (d) ZnSnPt/S-1.

(a) $\mathrm{ZnSnPt} / \mathrm{HZ} 30$; 


\subsection{Acidity of ZnSnPt Lewis Acid Sites over Defective MFI Zeolites with Different $\mathrm{SiO}_{2} / \mathrm{Al}_{2} \mathrm{O}_{3}$ Ratios}

The acidity of these samples is characterized by the FTIR spectra of the surface hydroxyl (OH-FTIR), $\mathrm{NH}_{3}$-TPD (Figures 5 and 6), and pyridine adsorbed FTIR spectra (Py-FTIR) (Figure S3). OH-FTIR spectra suggested that the defective ZSM- 5 contained Brønsted acid groups $\left(3610 \mathrm{~cm}^{-1}\right)$ associated with framework aluminum $(\mathrm{Si}(\mathrm{OH}) \mathrm{Al})$, isolated external silanol groups $\left(3740 \mathrm{~cm}^{-1}\right)$, free internal silanol groups $\left(3720 \mathrm{~cm}^{-1}\right)$, and hydroxyl nests (at around $3500 \mathrm{~cm}^{-1}$ ) that consist of a number of silanol groups interacting through extended hydrogen bonding [3,34,39]. The modification of the MFI zeolites with Zn, Sn and Pt species led the Brønsted acid sites and hydroxyl nests to simultaneously decrease. However, the decreasing of hydroxyl nests is much more significant suggesting that the $\mathrm{ZnSnPt}$ is mainly located in the hydroxyl nests. Moreover, with increase in the $\mathrm{SiO}_{2} / \mathrm{Al}_{2} \mathrm{O}_{3}$ ratios, the relative distance between the acid sites and $\mathrm{ZnSnPt}$ active sites also increased.
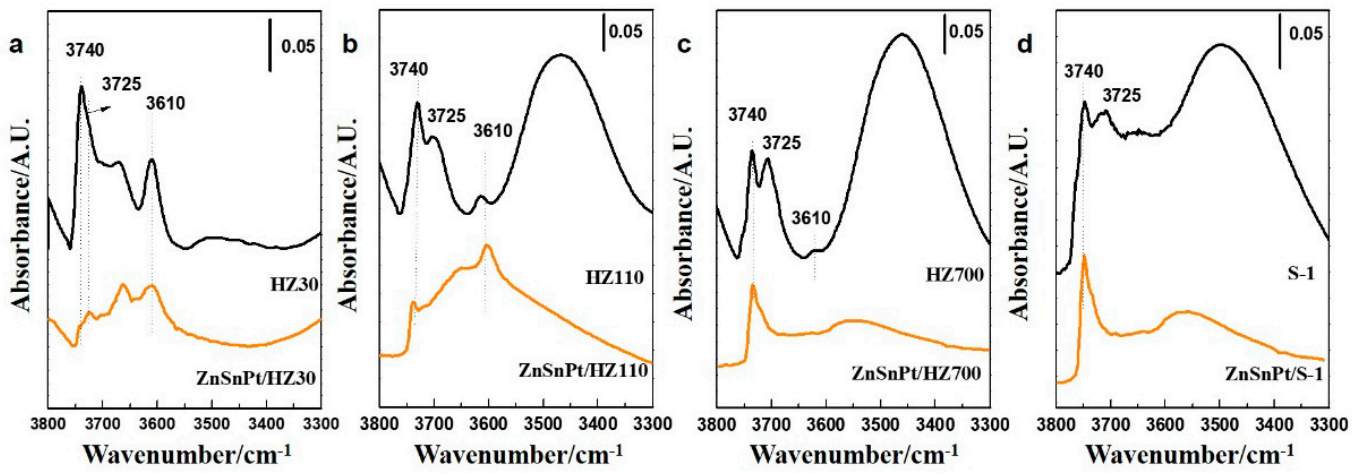

Figure 5. OH-FT-IR spectra of parent and Zn-Sn-Pt modified defective MFI zeolites with different $\mathrm{SiO}_{2} / \mathrm{Al}_{2} \mathrm{O}_{3}$ ratios. (a) $\mathrm{HZ} 30$ and $\mathrm{ZnSnPt} / \mathrm{HZ} 30$; (b) $\mathrm{HZ110}$ and $\mathrm{ZnSnPt} / \mathrm{HZ110}$; (c) $\mathrm{HZ700}$; $\mathrm{ZnSnPt} / \mathrm{HZ700}$; (d) S-1 and ZnSnPt/S-1.
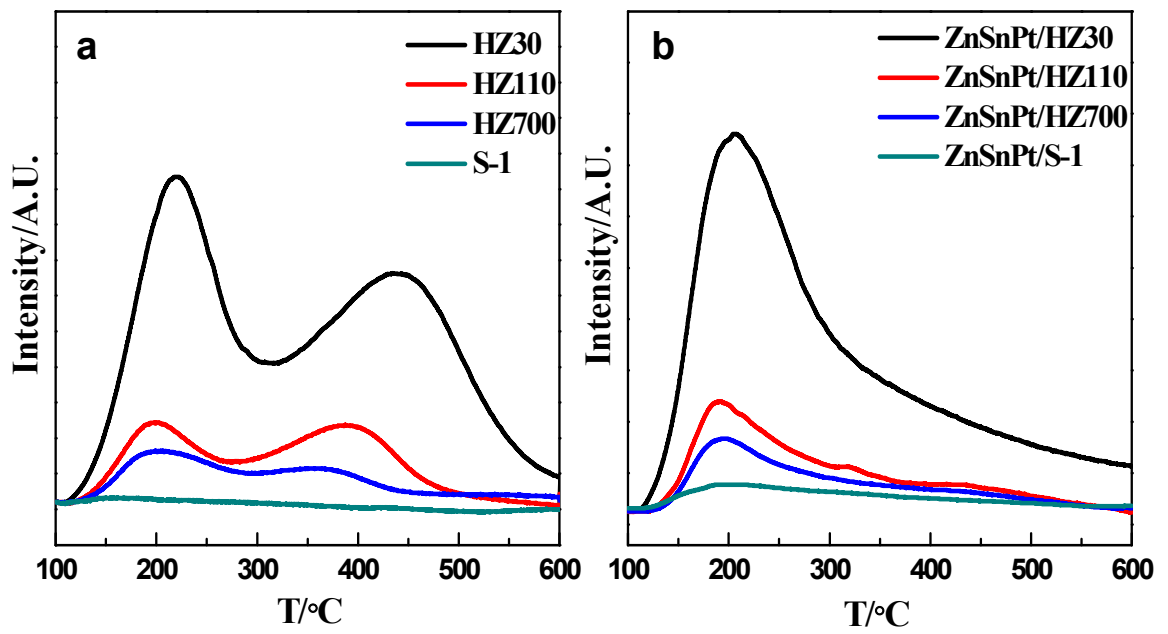

Figure 6. (a) The $\mathrm{NH}_{3}$-TPD profiles of defective MFI zeolites with different $\mathrm{SiO}_{2} / \mathrm{Al}_{2} \mathrm{O}_{3}$ ratios; (b) $\mathrm{Zn}-\mathrm{Sn}-\mathrm{Pt}$ modified defective MFI zeolites with different $\mathrm{SiO}_{2} / \mathrm{Al}_{2} \mathrm{O}_{3}$ ratios.

Generally, the $\mathrm{NH}_{3}$-TPD profiles of defective HZSM- 5 zeolites have two typical desorption peaks: one centered at about $230{ }^{\circ} \mathrm{C}$ and the other at $400^{\circ} \mathrm{C}$. The low temperature peak is associated with acid sites obtaining weak acidity $[40,41]$. The high temperature peak is associated with acid sites obtaining strong acidity. Due to the existence of $\mathrm{Si}(\mathrm{OH}) \mathrm{Al}$ groups with strong acid strength, the $\mathrm{Zn}$ modification also converts these $\mathrm{Si}(\mathrm{OH}) \mathrm{Al}$ groups with strong acidity into acid sites with medium and weak acidity. Thus, the overall amount of weak acid sites obtained by $\mathrm{NH}_{3}$-TPD profiles shows no decrease. Only a slight signal of $\mathrm{NH}_{3}$ desorption is obtained over the S-1 zeolite, demonstrating its weak acidic character. 
Over $\mathrm{ZnSnPt} / \mathrm{S}-1$ catalyst, the signals of $\mathrm{NH}_{3}$ desorption of the samples with $\mathrm{ZnSnPt}$ modification are strong that shows the stability of the $\mathrm{Zn}$ species on the hydroxyl nests can enhance the acidity of the ZnSnPt/S-1 zeolite.

In addition, Py-FTIR spectroscopy was carried out to follow the transformation of Brønsted and Lewis acid sites during the catalysts preparation. According to the Py-FTIR spectra of HZ110 and $\mathrm{ZnSnPt} / \mathrm{HZ110}$ in Figure S3, it can be seen that the absorbance at $1435 \mathrm{~cm}^{-1}$ attributed to the Lewis acid sites of the hydroxyl nests disappeared and a new peak that was attributed to the $\mathrm{Zn}$ Lewis acid sites appeared at $1450 \mathrm{~cm}^{-1}$. Similar phenomenas were also observed for the other samples. The absorbance at $1540 \mathrm{~cm}^{-1}$ attributed to the Brønsted acid sites, still existed after loading the metals over these samples. Therefore, according to the OH-IR and Py-IR results, the metals preferentially located on the hydroxyl nests showed weak acidity.

\subsection{Catalytic Performance of Zn-Sn-Pt Modified Defective MFI Zeolites with Different $\mathrm{SiO}_{2} / \mathrm{Al}_{2} \mathrm{O}_{3}$ Ratios}

The catalytic performance of parent and $\mathrm{ZnSnPt}$ modified defective MFI zeolites with different $\mathrm{SiO}_{2} / \mathrm{Al}_{2} \mathrm{O}_{3}$ ratios was tested by propane transformation. In Figure 7, it is obvious that the $\mathrm{ZnSnPt}$ modified defective MFI zeolites exhibit better catalytic performance than the parent zeolites. The $\mathrm{SiO}_{2} / \mathrm{Al}_{2} \mathrm{O}_{3}$ ratios of parent defective MFI zeolites have little significant effect on the propane product distribution. The selectivity in propane transformation over MFI zeolites is highly affected by the conversion degree and by the extension of consecutive reactions. The conversion of propane over the parent MFI zeolites with different $\mathrm{SiO}_{2} / \mathrm{Al}_{2} \mathrm{O}_{3}$ ratios is low. At low conversion levels, propane undergoes cracking reaction with large amount of methane, ethane, and ethylene as main products. These results suggest that the ability of the ZSM-5 parent zeolites to activate propane is poor. At higher conversion levels, the activation by the hydride transfer mechanism predominates due to the formation of BTX [42]. The conversion of propane is enhanced significantly after the incorporation of $\mathrm{Zn}$, $\mathrm{Sn}$, and Pt species. The hydroxyl nest incorporated $\mathrm{ZnSnPt}$ Lewis acid sites showed extraordinary dehydrogenation ability. Over $\mathrm{ZnSnPt} / \mathrm{MFI}$ catalysts, the decrease in the propane conversion with increasing $\mathrm{SiO}_{2} / \mathrm{Al}_{2} \mathrm{O}_{3}$ ratios is caused by the reduction in the number of Brønsted acid sites, which weakens the interaction between Brønsted acid sites and the metal Lewis acid sites. The selectivity of propylene increases with the $\mathrm{SiO}_{2} / \mathrm{Al}_{2} \mathrm{O}_{3}$ ratio of MFI zeolites. For $\mathrm{ZnSnPt} / \mathrm{HZ700}$, the propane conversion and propylene selectivity is $24.35 \%$ and $98.51 \%$, respectively. Moreover, for $\mathrm{ZnSnPt} / \mathrm{S}-1$, the propane conversion and propene selectivity is $19.05 \%$ and $96.43 \%$, respectively. For $\mathrm{ZnSnPt} / \mathrm{HZZ30}$, the selectivity of propylene and aromatics is $40.45 \%$ and $52.92 \%$, respectively, and the selectivity of $\mathrm{C}_{1}-\mathrm{C}_{2}$ alkanes is only $6.63 \%$, suggesting that when Brønsted acid sites are in close proximity to the high dispersion of metal clusters that are stably located on the hydroxyl nests, propane dehydrogenative aromatization occurred by synergistic catalysis between them.

In the propane aromatization process, the Brønsted acid sites are responsible for the oligomerization and cyclization, while Lewis acid sites catalyze the dehydrogenation of alkanes and cycloalkene intermediates. It is indicated that the difference in the propane transformation of $\mathrm{ZnSnPt} / \mathrm{MFI}$ zeolites with various hydroxyl nests concentration should be not only attributed to their different acidity, but also sensitive to the relative positions of different active centers. Regardless of this, an appropriate ratio between Brønsted acid sites and hydroxyl nests concentration of ZnSnPt/MFI catalysts can improve the selectivity of aromatics. However, a significant decrease in proximity between the Brønsted acid sites and the other active species inhibits the oligomerization and aromatization of olefins, conversely increasing the propylene selectivity. 

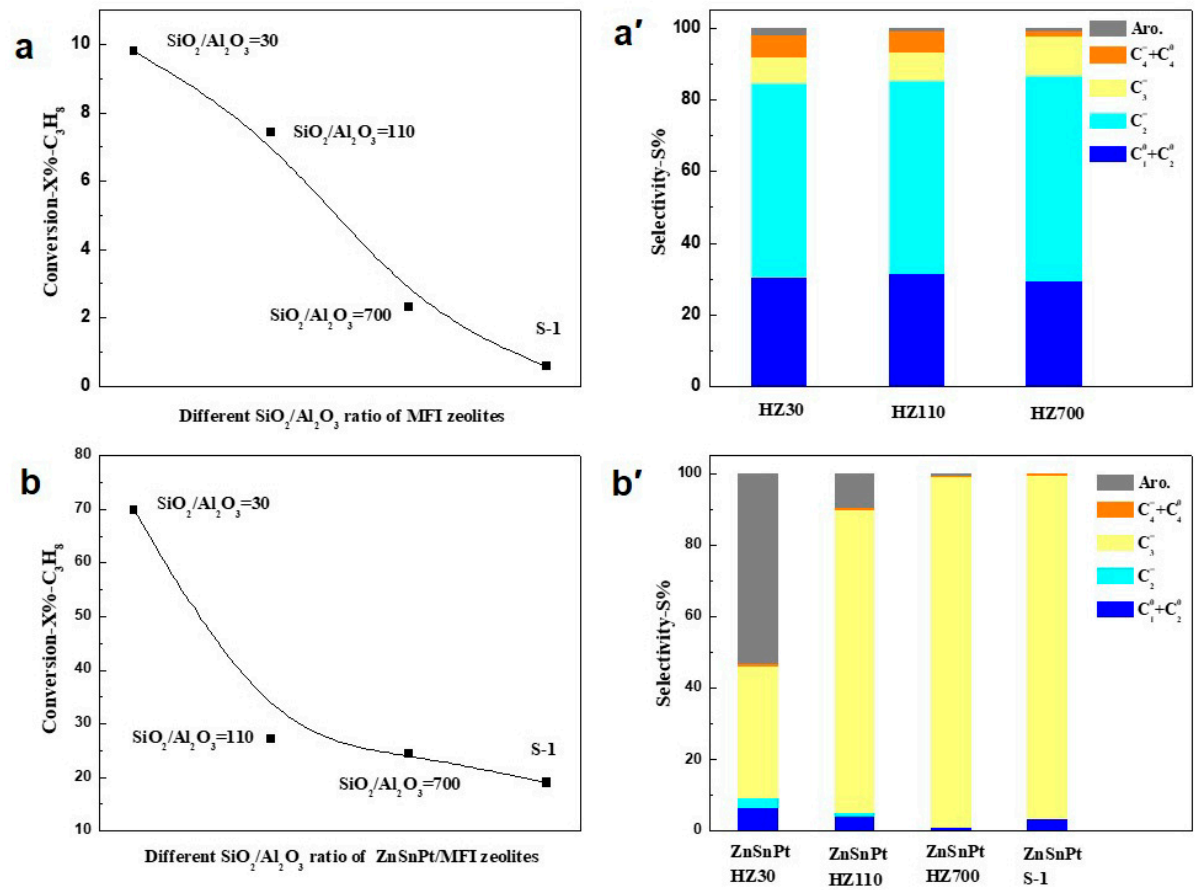

Figure 7. The performance of defective MFI zeolites $\left(\mathbf{a}, \mathbf{a}^{\prime}\right)$ and $\mathrm{Zn}-\mathrm{Sn}$-Pt modified defective MFI zeolites $\left(\mathbf{b}, \mathbf{b}^{\prime}\right)$ with different $\mathrm{SiO}_{2} / \mathrm{Al}_{2} \mathrm{O}_{3}$ ratios in propane transformation with a fixed-bed reactor. $\left(\mathrm{T}=610^{\circ} \mathrm{C}\right.$, $\mathrm{GHSV}=1800 \mathrm{~h}^{-1}$, atmospheric pressure).

In order to further investigate the stability of $\mathrm{ZnSnPt} / \mathrm{MFI}$ catalysts, a $30 \mathrm{~h}$ continuous propane transformation was performed. Figure 8 suggests that the conversion of propane and the selectivity of products over $\mathrm{ZnSnPt} / \mathrm{MFI}$ catalysts with different $\mathrm{SiO}_{2} / \mathrm{Al}_{2} \mathrm{O}_{3}$ ratios are stable during $30 \mathrm{~h}$ test.
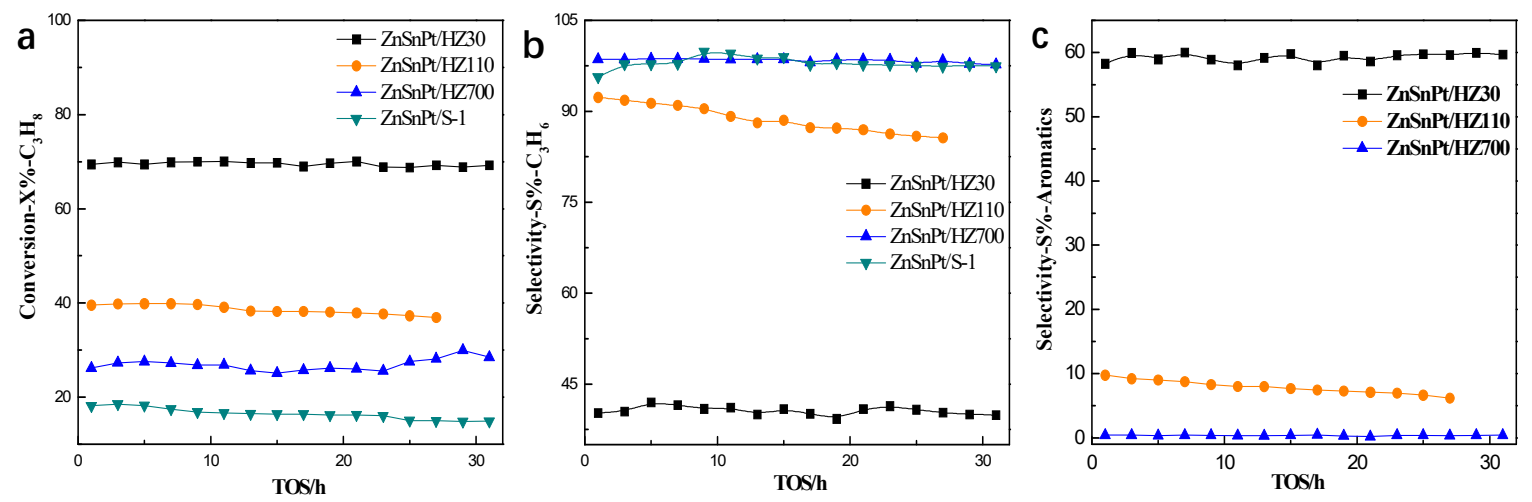

Figure 8. Stability test on $\mathrm{ZnSnPt} / \mathrm{MFI}$ catalyst with different $\mathrm{SiO}_{2} / \mathrm{Al}_{2} \mathrm{O}_{3}$ ratios. $\mathrm{T}=610{ }^{\circ} \mathrm{C}$, atmospheric pressure, GHSV $=1800 \mathrm{~h}^{-1}$. (a) The conversion of propane; (b) the selectivity of $\mathrm{C}_{3} \mathrm{H}_{6}$; (c) the selectivity of aromatics.

Operando DB-FTIR was employed to reveal the catalytic functions of $\mathrm{ZnSnPt} / \mathrm{MFI}$ zeolites with different $\mathrm{SiO}_{2} / \mathrm{Al}_{2} \mathrm{O}_{3}$ ratios (30,110, 700, and $\infty$ ) and hydroxyl nests concentration under propane reaction conditions. In order to get more detailed information, the selected FT-IR profiles (1350-1650, 2800-3050, and 3300-3800 $\mathrm{cm}^{-1}$ ) are displayed in Figure 9. Note that, in contrast to ZnSnPt modified defective MFI zeolites of high $\mathrm{SiO}_{2} / \mathrm{Al}_{2} \mathrm{O}_{3}$ ratios, propane is more strongly adsorbed over $\mathrm{ZnSnPt} / \mathrm{HZ} 30$ catalyst. As the temperature of propane adsorption enhanced, the absorbance of $\mathrm{Si}(\mathrm{OH}) \mathrm{Al}$ group at $3610 \mathrm{~cm}^{-1}$ obviously decreased (Figure 9a (1)), which indicated that the Brønsted acid sites participated in the propane transformation. However, the initial step on metal clusters through propane dissociative 
adsorption resulted in an obvious increase in surface $\mathrm{C}_{x} \mathrm{H}_{y}$ species (Figure $\left.9 \mathrm{a}(2)-(3)\right)$. The absorbance of $\mathrm{CH}_{3}$ and $\mathrm{CH}_{2}$ bending vibrations was at 1375, 1453 and $1395,1471 \mathrm{~cm}^{-1}$, respectively [34]. In addition, the absorbance at $1560 \mathrm{~cm}^{-1}$ could most likely be attributed to the precursors of aromatic compounds, and the absorbance at $1585 \mathrm{~cm}^{-1}$ attributed to $\mathrm{C}=\mathrm{C}$ double bond linked to $\mathrm{Zn}$ species $[34,43,44]$. In the presence of large number of Brønsted acid sites, the propane aromatization reaction was catalyzed by the cooperation between $\mathrm{ZnSnPt}$ metal sites and Brønsted acid sites. Over ZnSnPt/HZ110 catalyst, the $\mathrm{ZnSnPt}$ stably located on the hydroxyl nests and the absorbance of Brønsted acid sites slightly decreased with the increase in reaction temperature (Figure $9 b(1)$ ). This reveals that the amount of Brønsted acid sites involved in propane transformation is much lower than that of $\mathrm{ZnSnPt}$ Lewis acid sites. Therefore, only propylene is observed in the bending modes region (Figure 9b (3)). Abovementioned results suggest that the aromatization reaction is very sensitive to the location of the active center. When the Brønsted acid sites are far away from the other active site, the oligomerization and later aromatization of olefin intermediates are inhibited. Over ZnSnPt/S-1 catalyst, without the participation of Brønsted acid sites, the highly dispersed active species locating on the higher content of hydroxyl nests mainly catalyzed propane dehydrogenation. However, due to the weak adsorption and activation capacity of $\mathrm{ZnSnPt} / \mathrm{S}-1$ catalyst in propane transformation, the absorbance of $\mathrm{CH}_{3}$ and $\mathrm{CH}_{2}$ bending vibrations were not detected. This operando dual beam FTIR study suggests that the acidity of the neighboring active sites over the hydroxyl nest incorporated $\mathrm{ZnSnPt}$ Lewis acid sites determines the transformation paths of propane.
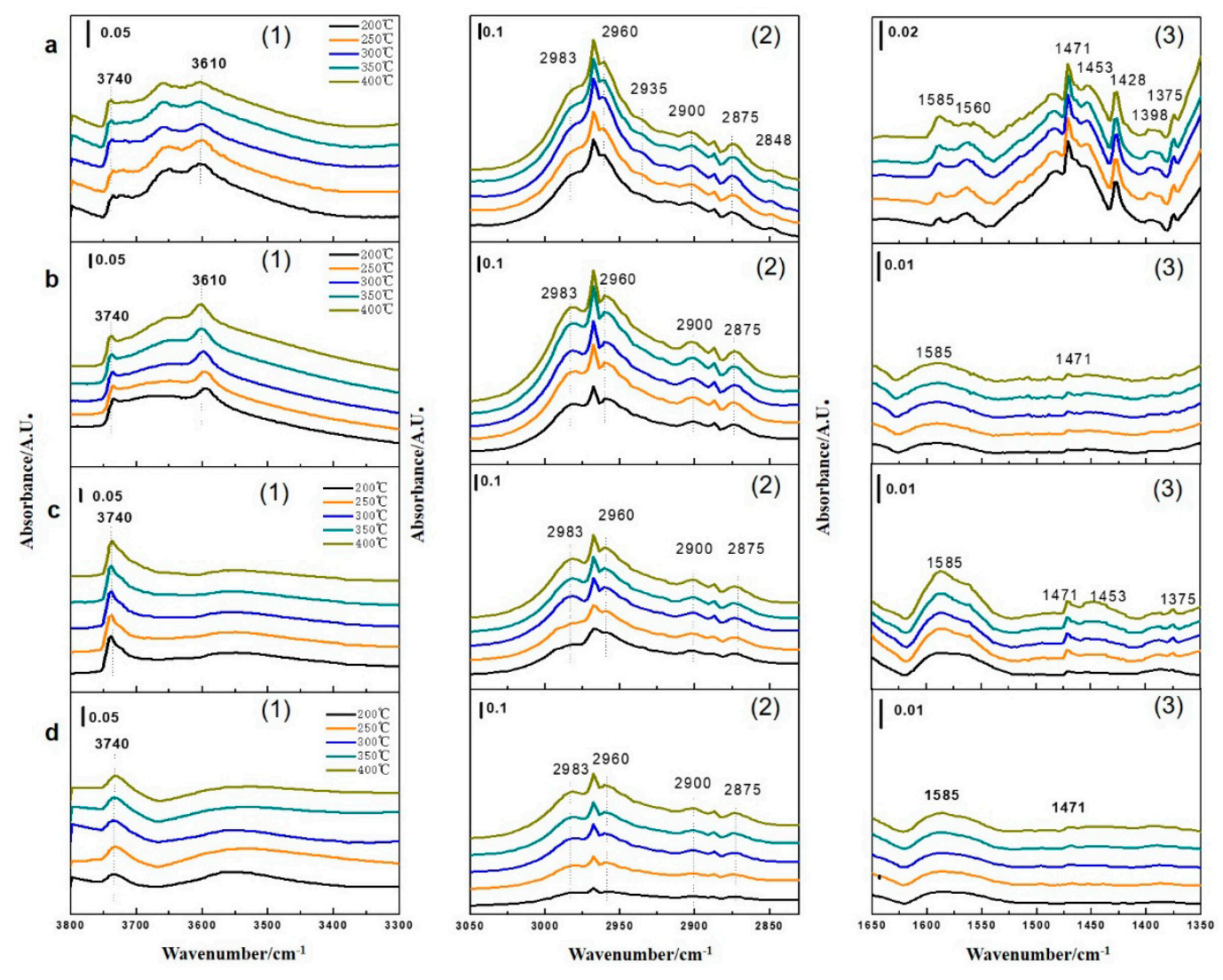

Figure 9. The operando DB-FT-IR spectra of propane transformation over (a) $\mathrm{ZnSnPt} / \mathrm{HZ30}$, (b) $\mathrm{ZnSnPt} / \mathrm{HZ110}$, (c) $\mathrm{ZnSnPt} / \mathrm{HZ700;} \mathrm{(d)} \mathrm{ZnSnPt} / \mathrm{S}-1$ catalysts. The feeding GHSV of propane was about $8 \mathrm{~h}^{-1}$. 


\section{Experimental Section}

\subsection{Materials}

Nano-sized silicalite-1(S-1) and defective H-ZSM-5 zeolites with different $\mathrm{SiO}_{2} / \mathrm{Al}_{2} \mathrm{O}_{3}$ ratios of 30, 110, and 700 were supplied by Dalian Ligong Qiwangda Chemical Technology (DQ-TECH), Dalian, China.

$\mathrm{Zn} / \mathrm{MFI}$ catalysts were prepared using the impregnation method at $353 \mathrm{~K}$ for $4 \mathrm{~h}$. The catalysts were dried at $383 \mathrm{~K}$ for $12 \mathrm{~h}$ and calcined at $813 \mathrm{~K}$ for $6 \mathrm{~h}$. The ZnSnPt/MFI catalysts were impregnated by successively loading stannum and platinum on the Zn/MFI catalysts. The modification catalysts were dried and calcined by the same method to obtain the $\mathrm{ZnSnPt} / \mathrm{MFI}$ catalysts. Catalysts modified by three metals with different $\mathrm{SiO}_{2} / \mathrm{Al}_{2} \mathrm{O}_{3}$ ratios were represented by $\mathrm{ZnSnPt} / \mathrm{HZ} 30, \mathrm{ZnSnPt} / \mathrm{HZ} 110$, $\mathrm{ZnSnPt} / \mathrm{HZ700}$, and ZnSnPt/S-1, respectively. Metal loadings measured by ICP are shown in Table S1.

\subsection{Characterization}

The amount of $\mathrm{Zn}, \mathrm{Sn}$, and Pt over ZnSnPt modified MFI zeolites was analyzed by inductively coupled plasma optical emission spectrometry (ICP-OES) using an optima 2000DV instrument. The $\mathrm{SiO}_{2} / \mathrm{Al}_{2} \mathrm{O}_{3}$ ratios were determined by $\mathrm{X}$-ray fluorescence $(\mathrm{XRF})$ measurements with a Bruker S8 TIGER spectrometer (Bruker, Madison, WI, USA). The surface morphology of zeolites was characterized by the scanning electron microscopy (SEM) on a Quanta 450 scanning electron microscope.

Nitrogen adsorption-desorption measurements were carried out with a Micrometrics ASAP 2020 instrument (Micromeritics, Atlanta, GA, USA) at $77^{\circ} \mathrm{C}$. Prior to measurements, the samples were pretreated in vacuum at $350^{\circ} \mathrm{C}$ for $6 \mathrm{~h}$. The classical Brunauer-Emmett-Teller (BET) model was used to calculate the specific surface area, while the t-plot method was used to discriminate the pore volume, the BJH method was applied to calculate the pore distribution.

The acidity of catalysts were characterized by OH-FTIR, Py-FTIR, and $\mathrm{NH}_{3}$-TPD methods. The FTIR spectra of the surface hydroxyl groups $(-\mathrm{OH})$ were recorded with a Nicolet is10 FT-IR spectrometer (Thermo Fisher Scientific, Waltham, MA, USA) in the region of $4000-400 \mathrm{~cm}^{-1}$ with a resolution of $4 \mathrm{~cm}^{-1}$. The catalysts were pretreated at $673 \mathrm{~K}$ under vacuum $\left(10^{-3} \mathrm{~Pa}\right)$ for $4 \mathrm{~h}$. After the cell was cooled down to $303 \mathrm{~K}$, the spectrum of OH-FTIR was recorded. Pyridine adsorbed FTIR spectra (Py-FTIR) were measured by a Nicolet 6700 spectrometer, and the background spectra were recorded in the region of $4000-400 \mathrm{~cm}^{-1}$ with a resolution of $4 \mathrm{~cm}^{-1}$ after pretreated in vacuation at $673 \mathrm{~K}$ for $4 \mathrm{~h}$. The catalysts were exposed to pyridine at room temperature for $0.5 \mathrm{~h}$. The wafers of catalyst samples containing chemisorbed pyridine were subjected to thermal treatment at $423 \mathrm{~K}$ in vacuum and cooled to room temperature, and then the IR spectra were recorded. $\mathrm{NH}_{3}$-TPD was performed to characterized the overall acidity of the catalysts with a Quantachrome ChemBet 3000 chemisorb instrument. First, $150 \mathrm{mg}$ catalysts were pretreated in He at $873 \mathrm{~K}$ for $1 \mathrm{~h}$. Then the catalysts were cooled down to $373 \mathrm{~K}$ to absorb $\mathrm{NH}_{3}$ for $0.5 \mathrm{~h}$. In order to remove physically adsorbed $\mathrm{NH}_{3}$, the catalyst samples were purged in He for $0.5 \mathrm{~h}$ with the flow rate of $50 \mathrm{~mL} \mathrm{~min}{ }^{-1}$. The $\mathrm{NH}_{3}-\mathrm{TPD}$ profiles were recorded from 373 to $873 \mathrm{~K}$ with a rate of $16 \mathrm{~K} \mathrm{~min}^{-1}$.

Transmission electron microscopy (TEM) images of the modified MFI zeolites were recorded on a microscopy (Tecnai F30 G2, FEI, Eindhoven, Netherlands).

The hydrogen temperature programmed reduction $\left(\mathrm{H}_{2}-\mathrm{TPR}\right)$ measurements were performed to study the interaction of metals by Quantachrome ChemBET Pulsar TPR/TPD Automated Chemisorption Analyser (Shimadzu, Kyoto, Japan). The samples were pretreated in He flow at $673 \mathrm{~K}$ for $0.5 \mathrm{~h}$, then cooled down to $303 \mathrm{~K} . \mathrm{H}_{2}$-TPR was performed by temperature programmed reduction in a mixture of $5 \% \mathrm{H}_{2}$ and $\mathrm{Ar}$ from $373 \mathrm{~K}$ to $1073 \mathrm{~K}$ at a rate of $10 \mathrm{~K} \mathrm{~min}^{-1}$.

Operando DB-FT-IR study was applied to unravel the role of $\mathrm{Zn}, \mathrm{Sn}$, and $\mathrm{Pt}$ in propane transformation under real reaction conditions $[28,38,45]$. The catalysts were pressed into thin wafers, then pretreated in vacuum $\left(10^{-3} \mathrm{~Pa}\right)$ at $673 \mathrm{~K}$ for $4 \mathrm{~h}$. After the cell was cooled down to $303 \mathrm{~K}$, the background spectra were recorded in the region of $4000-400 \mathrm{~cm}^{-1}$ with a resolution of $4 \mathrm{~cm}^{-1}$. 
After that, the dual beam IR-cell reactor was filled with diluted propane ( $1 \%$ propane in $\mathrm{N}_{2}$ ). Propane transformation was performed from $323 \mathrm{~K}$ to $673 \mathrm{~K}$ under the pressure of $0.1 \mathrm{MPa}$. Finally, the spectra were recorded by subtracting the background spectrum from the sample spectra.

\subsection{Propane Transformation}

The propane transformation was performed in a fixed-bed reactor. The reaction tube with an inner diameter of $10 \mathrm{~mm}$ was filled with $1 \mathrm{~g}$ catalyst. The propane transformation was carried out at $883 \mathrm{~K}, 0.1 \mathrm{Mpa}$, and GHSV was $1800 \mathrm{~h}^{-1}$. The mass balance was obtained by weighing the gross weight of feedstock and products. Coke deposits over samples were ignored. The reaction products were analyzed with an online GC-14C gas chromatography.

\section{Conclusions}

Hydroxyl nest incorporated $\mathrm{ZnSnPt}$ Lewis acid sites showed extraordinary dehydrogenation ability over the defective MFI zeolites. The increase in the concentration of hydroxyl nests and $\mathrm{SiO}_{2} / \mathrm{Al}_{2} \mathrm{O}_{3}$ ratios apparently improved the distribution of $\mathrm{ZnSnPt}$ Lewis acid sites. Operando dual beam FTIR study showed that the acidity and distance of neighboring active sites over the hydroxyl nest incorporated $\mathrm{ZnSnPt}$ Lewis acid sites determines the propane transformation paths. At low $\mathrm{SiO}_{2} / \mathrm{Al}_{2} \mathrm{O}_{3}$ ratios, the propane efficiently transformed into aromatics by the cooperation of the neighboring Brønsted acid sites and $\mathrm{ZnSnPt}$ Lewis acid sites. While at high $\mathrm{SiO}_{2} / \mathrm{Al}_{2} \mathrm{O}_{3}$ ratios, the propylene is mainly generated by cooperation of neighboring hydroxyl nests and $\mathrm{ZnSnPt}$ Lewis acid sites.

Supplementary Materials: The following are available online at http://www.mdpi.com/2073-4344/9/7/571/s1, Figure S1: XRD profiles of $\mathrm{ZnSnPt} / \mathrm{MFI}$ zeolites with different $\mathrm{SiO}_{2} / \mathrm{Al}_{2} \mathrm{O}_{3}$ ratios. Figure $\mathrm{S} 2: \mathrm{H}_{2}-\mathrm{TPR}$ profiles of $\mathrm{Sn}$ or Pt modified defective MFI zeolites.

Author Contributions: J.L. and H.G. supervised the work; W.Z. and J.L. conceptualized and designed the experiments, analyzed the results, and wrote the manuscript; W.Z. performed the catalyst preparation, characterization and catalytic tests; L.L. and X.Z. performed the $\mathrm{NH}_{3}$-TPD measurement; N.H. performed the argon physisorption measurements.

Funding: This research was funded supported by the National Natural Science Foundation of China, grant number 21603023 and the Joint Fund Project of NSFC-Liaoning Province, grant number U1508205.

Conflicts of Interest: The authors declare no conflict of interest.

\section{References}

1. Weitkamp, J.; Traa, Y. Isobutane/butene alkylation on solid catalysts. Where do we stand? Catal. Today 1999, 49, 193-199. [CrossRef]

2. Barrer, R.M.; Makki, M.B. Molecular sieve sorbents from clinoptilolite. Can. J. Chem. 1964, 42, 1481-1487. [CrossRef]

3. Bordiga, S.; Ugliengo, P.; Damina, A.; Lamberti, C.; Spoto, G.; Zecchin, A.; Spano, G.; Buzzoni, R.; Dalloro, L.; Rivetti, F. Hydroxyls nests in defective silicalites and strained structures derived upon dehydroxylation: Vibrational properties and theoretical modelling. Top. Catal. 2001, 15, 43-52. [CrossRef]

4. Heitmann, G.P.; Dahlhoff, G.; Niederer, J.P.M.; Hölderich, W.F. Active Sites of a [B]-ZSM-5 Zeolite Catalyst for the Beckmann Rearrangement of Cyclohexanone Oxime to Caprolactam. J. Catal. 2000, 194, 122-129. [CrossRef]

5. Zecchina, A.; Bordiga, S.; Spoto, G.; Marchese, L.; Petrini, G.; Leofanti, G.; Padovan, M. Silicalite characterization. Structure, adsorptive capacity, and IR spectroscopy of the framework and hydroxyl modes. J. Phys. Chem. 1992, 96, 4985-4990. [CrossRef]

6. Jia, Y.M.; Wang, J.W.; Zhang, K.; Liu, S.B.; Chen, G.L.; Yang, Y.F.; Ding, C.M.; Liu, P. Catalytic conversion of methanol to aromatics over nanosized HZSM-5 zeolite modified by $\mathrm{ZnSiF}_{6} \cdot 6 \mathrm{H}_{2} \mathrm{O}$. Catal. Sci. Technol. 2012, 7, 1776-1791. [CrossRef]

7. Bleken, F.L.; Barbera, K.; Bonino, F.; Olsbye, U.; Lillerud, K.P.; Bordiga, S.; Beato, P.; Janssens, T.V.W.; Svelle, S. Catalyst deactivation by coke formation in microporous and desilicated zeolite H-ZSM-5 during the conversion of methanol to hydrocarbons. J. Catal. 2013, 307, 62-73. [CrossRef] 
8. Heitmann, G.P.; Dahlhoff, G.; Holderich, W.F. Catalytically active sites for the beckmann rearrangement of cyclohexanone oxime to $\varepsilon$-caprolactam. J. Catal. 1999, 186, 12-19. [CrossRef]

9. Chen, N.; Yan, T.Y. M2 forming-a process for aromatization of light hydrocarbons. Ind. Eng. Chem. Process Des. Dev. 1986, 25, 151-155. [CrossRef]

10. Ono, Y. Transformation of Lower Alkanes into Aromatic Hydrocarbons over ZSM-5 Zeolites. Catal. Rev. 2006, 34, 179-226. [CrossRef]

11. Biscardi, J.A.; Iglesia, E. Structure and function of metal cations in light alkane reactions catalyzed by modified H-ZSM5. Catal. Today 1996, 31, 207-231. [CrossRef]

12. Vermeiren, W.; Gilson, J.P. Impact of Zeolites on the Petroleum and Petrochemical Industry. Top. Catal. 2009, 52, 1131-1161. [CrossRef]

13. Kokotailo, G.T.; Lawton, S.L.; Olson, D.H. Structure of synthetic zeolite ZSM-5. Nature 1978, 272, 437-438. [CrossRef]

14. Venuto, P.B. Organic catalysis over zeolites: A perspective on reaction paths within micropores. Microporous Mater. 1994, 2, 297-411. [CrossRef]

15. Guisnet, M.; Gnep, N.S. Aromatization of short chain alkanes on zeolite catalysts. Appl. Catal. A Gen. 1992, 89, 1-30. [CrossRef]

16. Ausavasukhi, A.; Sooknoi, T. Tunable activity of [Ga]HZSM-5 with $\mathrm{H}_{2}$ treatment: Ethane dehydrogenation. Catal. Commun. 2014, 45, 63-68. [CrossRef]

17. Schreiber, M.W.; Plaisance, C.P.; Baumgartl, M.; Reuter, K.; Jentys, A.; Bermejo-Deval, R.; Lercher, J.A. Lewis-Bronsted Acid Pairs in Ga/H-ZSM-5 To Catalyze Dehydrogenation of Light Alkanes. J. Am. Chem. Soc. 2018, 140, 4849-4859. [CrossRef] [PubMed]

18. Krishnamurthy, G.; Bhan, A.; Delgass, W.N. Identity and chemical function of gallium species inferred from microkinetic modeling studies of propane aromatization over Ga/HZSM-5 catalysts. J. Catal. 2010, 271, 370-385. [CrossRef]

19. Bhan, A.; Nicholas Delgass, W. Propane Aromatization over HZSM-5 and Ga/HZSM-5 Catalysts. Catal. Rev. 2008, 50, 19-151. [CrossRef]

20. Mole, T.; Anderson, J.R.; Creer, G. The reaction of propane over ZSM-5-H and ZSM-5-Zn zeolite catalysts. Appl. Catal. 1985, 17, 141-154. [CrossRef]

21. Gabrienko, A.A.; Arzumanov, S.S.; Toktarev, A.V.; Danilova, I.G.; Prosvirin, I.P.; Kriventsov, V.V.; Zaikovskii, V.I.; Freude, D.; Stepanov, A.G. Different Efficiency of $\mathrm{Zn}^{2+}$ and $\mathrm{ZnO}$ Species for Methane Activation on Zn-Modified Zeolite. ACS Catal. 2017, 7, 1818-1830. [CrossRef]

22. Mehdad, A.; Lobo, R.F. Ethane and ethylene aromatization on zinc-containing zeolites. Catal. Sci. Technol. 2017, 7, 3562-3572. [CrossRef]

23. Chen, X.; Dong, M.; Niu, X.; Wang, K.; Chen, G.; Fan, W.; Wang, J.; Qin, Z. Influence of Zn species in HZSM-5 on ethylene aromatization. Chin. J. Catal. 2015, 36, 880-888. [CrossRef]

24. Saito, H.; Inagaki, S.; Kojima, K.; Han, Q.; Yabe, T.; Ogo, S.; Kubota, Y.; Sekine, Y. Preferential dealumination of Zn/H-ZSM-5 and its high and stable activity for ethane dehydroaromatization. Appl. Catal. A Gen. 2018, 549, 76-81. [CrossRef]

25. Tamiyakul, S.; Sooknoi, T.; Lobban, L.L.; Jongpatiwut, S. Generation of reductive Zn species over Zn/HZSM-5 catalysts for n-pentane aromatization. Appl. Catal. A Gen. 2016, 525, 190-196. [CrossRef]

26. Gong, T.; Qin, L.; Lu, J.; Feng, H. ZnO modified ZSM-5 and Y zeolites fabricated by atomic layer deposition for propane conversion. Phys. Chem. Chem. Phys. 2016, 18, 601-614. [CrossRef] [PubMed]

27. Liu, J.X.; He, N.; Zhao, Y.; Lin, L.; Zhou, W.; Xiong, G.; Xie, H.B.; Guo, H.C. The Crucial Role of Skeleton Structure and Carbon Number on Short-Chain Alkane Activation over Zn/HZSM-5 Catalyst: An Experimental and Computational Study. Catal. Lett. 2018, 148, 2069-2081. [CrossRef]

28. Liu, J.X.; He, N.; Zhou, W.; Lin, L.; Liu, G.D.; Liu, C.Y.; Wang, J.L.; Xin, Q.; Xiong, G.; Guo, H.C. Isobutane aromatization over a complete Lewis acid Zn/HZSM-5 zeolite catalyst: Performance and mechanism. Catal. Sci. Technol. 2018, 8, 4018-4029. [CrossRef]

29. Liu, G.D.; Liu, J.X.; He, N.; Miao, C.L.; Wang, J.L.; Xin, Q.; Guo, H.C. Silicalite-1 zeolite acidification by zinc modification and its catalytic properties for isobutane conversion. RSC Adv. 2018, 8, 18663-18671. [CrossRef]

30. Almutairi, S.M.T.; Mezari, B.; Magusin, P.C.M.M.; Pidko, E.A.; Hensen, E.J.M. Structure and Reactivity of Zn-Modified ZSM-5 Zeolites: The Importance of Clustered Cationic Zn Complexes. ACS Catal. 2011, 2, 71-83. [CrossRef] 
31. Wu, J.F.; Wang, W.D.; Xu, J.; Deng, F.; Wang, W. Reactivity of C1 surface species formed in methane activation on Zn-modified H-ZSM-5 zeolite. Chemistry 2010, 16, 14016-14025. [CrossRef] [PubMed]

32. Pidko, E.A.; van Santen, R.A. Activation of Light Alkanes over Zinc Species Stabilized in ZSM-5 Zeolite: A Comprehensive DFT Study. J. Phys. Chem. C 2007, 111, 2643-2655. [CrossRef]

33. Barbosa, L.A.M.; Zhidomirov, G.M.; van Santen, R.A. Theoretical Study of the Molecular Hydrogen Adsorption and Dissociation on Different Zn(II) Active Sites of Zeolites. Catal. Lett. 2001, 77, 55-62. [CrossRef]

34. Kolyagin, Y.; Ordomsky, V.; Khimyak, Y.; Rebrov, A.; Fajula, F.; Ivanova, I. Initial stages of propane activation over Zn/MFI catalyst studied by in situ NMR and IR spectroscopic techniques. J. Catal. 2006, 238, 122-133. [CrossRef]

35. Barbosa, L.A.M.M.; van Santen, R.A. Study of the Activation of C-H and H-H Chemical Bonds by the $[\mathrm{ZnOZn}]^{2+}$ Oxycation:Influence of the Zeolite Framework Geometry. J. Phys. Chem. B 2003, 107, 14342-14349. [CrossRef]

36. Zhou, W.; Liu, J.; Wang, J.; Lin, L.; Zhang, X.; He, N.; Liu, C.; Guo, H. Enhancing Propane Aromatization Performance of Zn/H-ZSM-5 Zeolite Catalyst with Pt Promotion: Effect of the Third Metal Additive-Sn. Catal. Lett. 2019, 149, 2064-2077. [CrossRef]

37. Lin, L.; Zhang, X.; He, N.; Liu, J.; Xin, Q.; Guo, H. Operando Dual Beam FTIR Study of Hydroxyl Groups and Zn Species over Defective HZSM-5 Zeolite Supported Zinc Catalysts. Catalysts 2019, 9, 100. [CrossRef]

38. Zhou, W.; Liu, J.X.; Lin, L.; Zhang, X.T.; He, N.; Liu, C.Y.; Guo, H.C. Enhanced dehydrogenative aromatization of propane by incorporating Fe and Pt into Zn/HZSM-5 catalyst. Ind. Eng. Chem. Res. 2018, 57, 16246-16256. [CrossRef]

39. Bordiga, S.; Roggero, I.; Ugliengo, P.; Zecchina, A.; Bolis, V.; Artioli, G.; Buzzoni, R.; Marra, G.; Rivetti, F.; Spanò, G.; et al. Characterization of defective silicalites. J. Chem. Soc. Dalton Trans. 2000, 21, 3921-3929. [CrossRef]

40. Li, Y.; Liu, S.; Xie, S.; Xu, L. Promoted metal utilization capacity of alkali-treated zeolite: Preparation of Zn/ZSM-5 and its application in 1-hexene aromatization. Appl. Catal. A Gen. 2009, 360, 8-16. [CrossRef]

41. Bolis, V.; Busco, C.; Bordiga, S.; Ugliengo, P.; Lamberti, C.; Zecchina, A. Calorimetric and IR spectroscopic study of the interaction of $\mathrm{NH}_{3}$ with variously prepared defective silicalites: Comparison with ab initio computational data. Appl. Surf. Sci. 2002, 196, 56-70. [CrossRef]

42. Ono, Y.; Kanae, K. Transformation of butanes over ZSM-5 zeolites. Part 1.-Mechanism of cracking of butanes over H-ZSM-5. J. Chem. Soc. Faraday Trans. 1991, 87, 663-667. [CrossRef]

43. Kolyagin, Y.G.; Ivanova, I.I.; Pirogov, Y.A. (1)H and (13)C MAS NMR studies of light alkanes activation over MFI zeolite modified by Zn vapour. Solid State Nucl. Magn. Reson. 2009, 35, 104-112. [CrossRef] [PubMed]

44. Ivanova, I.I.; Kolyagin, Y.G.; Ordomsky, V.V.; Asachenko, E.V.; Pasynkova, E.M.; Pirogov, Y.A. Surface species formed during propane aromatization over Zn/MFI catalyst as determined by in situ spectroscopic techniques. J. Mol. Catal. A Chem. 2009, 305, 47-53. [CrossRef]

45. Liu, J.X.; Wang, J.L.; Zhou, W.; Miao, C.L.; Xiong, G.; Xin, Q.; Guo, H.C. Construction of an operando dual-beam fourier transform infrared spectrometer and its application in the observation of isobutene reactions over nano-sized HZSM-5 zeolite. Chin. J. Catal. 2017, 38, 13-19. [CrossRef]

(C) 2019 by the authors. Licensee MDPI, Basel, Switzerland. This article is an open access article distributed under the terms and conditions of the Creative Commons Attribution (CC BY) license (http://creativecommons.org/licenses/by/4.0/). 